\title{
PEMODELAN ANGKA PORI PADA STABILISASI TANAH GAMBUT
}

\author{
Mohammad Syaiful Pradana ${ }^{1}$, Awawin Mustana Rohmah ${ }^{2}$ \\ 1,2 Pendidikan Matematika, Fakultas Keguruan dan Ilmu Pendidikan, Universitas Islam Darul Ulum Lamongan \\ syaifulp@unisda.ac.id
}

\begin{abstract}
Methods for improving peat soils to increase soil carrying capacity and reduce environmentally sound soil compressibility, namely stabilization of the peat layer. This method uses additives such as lime, fly ash and husks. This method has been developed based laboratory by civil engineers. However, it takes a relatively long time to find out the laboratory results. Therefore, research in the field of mathematical models for stabilization of peat soil was developed to predict the laboratory results. In this study, a mathematical model was derived one of the physical properties of peat soil, that is the pore number in stabilizing peat soil. The model is derived from fluid equations through porous media based on the principle of continuum and control volume. Furthermore, the model is completed using a finite difference method, the MacCormack scheme which consists of two steps, that are predictor and corrector. After the model is simulated using matlab, it is known that there is a decrease in the soil pore value to a constant condition. This decrease in pore number is due to chemical reactions that occur by additives which make the soil pores smaller.
\end{abstract}

Keywords: pore number, maccormack, stabilization of peat soil

\section{PENDAHULUAN}

Tanah gambut memiliki kompresibilitas tinggi dan daya dukung sangat rendah. Kondisi tersebut membuat para civil engineer mengembangkan metode untuk memperbaiki tanah dengan mengurangi kompresibilitas dan meningkatkan daya dukung tanah. Agar dalam pembangunan pondasi sipil diatasnya menjadi lebih kuat. Menurut (Muhammad Afief Ma'ruf \& Yulianto, 2017), metode stabilisasi menjadi salah satu metode yang lebuh berwawasan lingkungan dan murah dibandingkan dengan metode lain. Metode stabilisasi dikembangkan menggunakan bahan aditif seperti kapur, abu terbang dan sekam.

Beberapa penelitian berbasis laboratorium mengenai stabilisasi tanah gambut telah dikembangkan di Indonesia. (Yulianto \& Mochtar, 2012) mengembangkan metode stabilisasi tanah gambut dengan $70 \%$ abu sekam padi dan $30 \%$ kapur. Tanah gambut yang distabilkan dengan $10 \%$ bahan campuran tersebut memberikan kenaikan kapasitas bantalan optimum dan penurunan kompresibilitas sehingga perbaikan tanah menjadi lebih baik seiring bertambahnya waktu. Menurut (M Afief Ma'ruf \& Syauqiah, 2017), menyimpulkan bertambahnya umur stabilisasi maka reaksi bahan stabilisasi akan semakin lama pula. Menurut (Yulianto, Mochtar, \& Wardani, 2016), penurunan kadar air pada gambut menyebabkan angka pori menjadi lebih kecil sehingga kompressibilitas menurun.
Penelitian berbasis laboratorium membutuhkan waktu yang relative lama untuk mengetahui hasil laboratorium. Oleh karena itu, penelitian dibidang model matematika untuk stabilisasi tanah gambut dikembangkan untuk dapat memprediksi hasil laboratorium tersebut.

Parameter-parameter sifat fisik tanah gambut antara lain kadar air, spesifik gravity, angka pori, kadar organic, keasaman, kadar abu, rembesan, kadar gas, berat volume dan batas konsistensi. Pada paper ini membahas mengenai parameter angka pori. Menurut (Pradana \& Muniroh, 2016) aliran dalam pori bergerak relatif lambat dan dapat dimodelkan melalui hukum kekekalan massa.

Untuk mendapatkan model angka pori tersebut. Model diturunkan dari persamaan fluida melalui media berpori berdasakan prinsip kontinum dan volume kendali. Selanjutnya, model diselesaikan menggunakan metode beda hingga skema MacCormack yang terdiri atas dua langkah yaitu predictor dan korektor. Dalam langkah predictor menggunakan beda maju dan langkah korektor menggunakan beda mundur. Menurut (Pradana \& Rohmah, 2018) skema MacCormack memliki kelebihan dalam menyelesaikan persamaan aliran fluida dan kontinuitas. 


\section{METODE}

Model matematika dari stabilisasi tanah gambut di laboratorium diturunkan berdasarkan prinsip kontinum dan volume kendali menggunakan persamaan kekekalan massa pada media berpori.

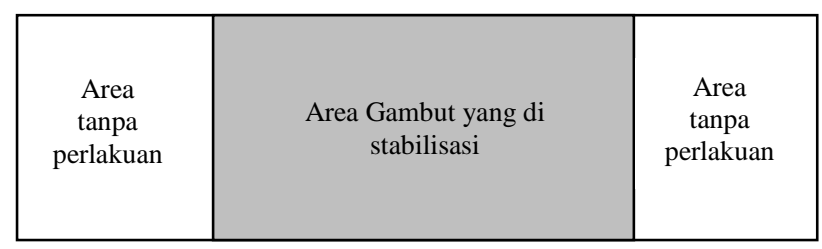

Gambar 1. Model Stabilisasi Tanah Gambut

Dari gambar 1 sketsa model stabilisasi tanah gambut di laboratorium dihasilkan model matematika untuk mengetahui prilaku pertumbuhan kristal yang dibentuk dari reaksi kimia dari gambut, kapur, abu terbang (fly ash) dan air (Pradana \& Widodo, 2014).

Prinsip fisik pertama yang diterapkan untuk konversi dari sistem ke deskripsi volume kontrol adalah prinsip konservasi massa yaitu massa sistem tetap konstan (Pritchard, 2011).

Dengan

$$
\left.\frac{d M}{d t}\right)_{\text {sistem }}=0
$$

$$
M_{\text {sistem }}=\int_{M(\text { sistem })} d m=\int_{V(\text { sistem })} \rho d V
$$

Formulasi sistem dan kontrol volume ditunjukkan pada persamaan (2) berikut

$$
\left.\frac{d N}{d t}\right)_{\text {sistem }}=\frac{\partial}{\partial t} \int_{C V} \eta \rho d V=\int_{C S} \eta \rho \vec{V} \cdot d \vec{A}
$$

Dengan

$$
N_{\text {sistem }}=\int_{M(\text { sistem })} \eta d m=\int_{V(\text { sistem })} \eta \rho d V
$$

Untuk mendapatkan formulasi kontrol volume dari konservasi massa, dimisalkan $N=M$. Selanjutnya dengan subtitusikannya ke persamaan (2) didapatkan

$$
\left.\frac{d M}{d t}\right)_{\text {sistem }}=\frac{\partial}{\partial t} \int_{C V} \rho d V=\int_{C S} \rho \vec{V} \cdot d \vec{A}
$$

Selanjutnya dengan membandingkan persamaan (1) dan (3) didapatkan formulasi volume kendali dari konservasi massa sebagai berikut.

$$
\frac{\partial}{\partial t} \int_{C V} \rho d V+\int_{C S} \rho \vec{V} \cdot d \vec{A}=0
$$

Angka pori (e) merupakan perbandingan antara volume pori dengan volume solid. Sedangkan porositas merupakan perbandingan antara volume pori dengan volume tanah, biasanya ditulis dalam bentuk persentase atau desimal. Jika volume pori adalah $\phi$ maka volume solid adalah $(1-\phi)$. Sehingga dapat didefinisikan

$$
e=\frac{\phi}{1-\phi} \text { dan } \phi=\frac{e}{1+e}
$$

Dalam metode beda hingga terdapat skema eksplisit dan implisit. Skema MacCormack merupakan salah satu skema eksplisit dalam metode beda hingga. Berikut contoh persamaan aliran satu dimensi menggunakan skema MacCormack.

$$
\frac{\partial u}{\partial t}+a \frac{\partial u}{\partial x}=0
$$

Tahap prediktor : pada tahap ini menggunakan skema maju, nilai sementara dari $u$ pada watu $n+1$ didenotasikan oleh $u_{i}^{\overline{n+1}}$ sehingga didapatkan

$$
u_{i}^{\overline{n+1}}=u_{i}^{n}-a \frac{\Delta t}{\Delta x}\left(u_{i+1}^{n}-u_{i}^{n}\right)
$$

Tahap korektor : pada tahap ini menggunakan skema mundur, nilai predictor $u_{i}^{\overline{n+1}}$ dikoreksi berdasarkan persamaan (8) berikut.

$$
u_{i}^{n+1}=u_{i}^{n+\frac{1}{2}}-a \frac{\Delta t}{2 \Delta x}\left(u_{i}^{\overline{n+1}}-u_{i-1}^{\overline{n+1}}\right)
$$

Step waktu yang digunakan dalam tahap korektor adalah $\frac{\Delta t}{2}$ dan mengganti bentuk $u_{i}^{n+\frac{1}{2}}$ dengan rata-rata sementara

$$
u_{i}^{n+\frac{1}{2}}=\frac{u_{i}^{n}-u_{i}^{\overline{n+1}}}{2}
$$

Sehingga diperoleh tahap korektor sebagai berikut.

$$
u_{i}^{n+1}=\frac{1}{2}\left[u_{i}^{n}+\left[u_{i}^{\overline{n+1}}-a \frac{\Delta t}{2 \Delta x}\left(u_{i}^{\overline{n+1}}-u_{i-1}^{\overline{n+1}}\right)\right]\right]
$$

\section{HASIL DAN PEMBAHASAN}

Stabilisasi dalam paper ini menggunakan bahan campuran fly ash, kapur dan air. Berikut reaksi kimia yang dihasilkan oleh bahan campuran tersebut.

$$
\begin{gathered}
\mathrm{CaCO}_{3}+\mathrm{H}_{2} \mathrm{O} \rightarrow \mathrm{Ca}(\mathrm{OH})_{2}+\mathrm{CO}_{2} \\
\mathrm{SiO}_{2}+\mathrm{H}_{2} \mathrm{O} \rightarrow \mathrm{H}_{2} \mathrm{SiO}_{3} \\
\mathrm{Ca}(\mathrm{OH})_{2}+2 \mathrm{H}_{2} \mathrm{SiO}_{3} \rightarrow \mathrm{Ca}\left(\mathrm{HSiO}_{3}\right)+2 \mathrm{H}_{2} \mathrm{O}
\end{gathered}
$$

Dengan $\mathrm{Ca}(\mathrm{OH})_{2}$ adalah kalsium hidroksida, $\mathrm{CO}_{2}$ adalah karbon dioksida, $\mathrm{H}_{2} \mathrm{SiO}_{3}$ adalah asam silicid.

Tabel 1. Reaksi Stoikiometri

\begin{tabular}{|c|c|c|}
\hline Senyawa & Koefisien & Molar \\
\hline $\mathrm{Ca}(\mathrm{OH})_{2}$ & 1 & 74,09 \\
\hline $\mathrm{H}_{2} \mathrm{SiO}_{3}$ & 2 & 78,10 \\
\hline $\mathrm{Ca}\left(\mathrm{HSiO}_{3}\right)_{2}$ & 1 & 194,26 \\
\hline $\mathrm{H}_{2} \mathrm{O}$ & 2 & 18,02 \\
\hline
\end{tabular}

dengan $_{k}=\frac{\left[\mathrm{Ca}\left(\mathrm{HSiO}_{3}\right)\right]\left[\mathrm{H}_{2} \mathrm{O}\right]}{\left[\mathrm{Ca}(\mathrm{OH})_{2}\right]\left[\mathrm{H}_{2} \mathrm{SiO}_{3}\right]}=\frac{3500,57}{5786,43}=0,60$ 
Untuk mengetahui laju reaksi dari bahan campuran tersebut, dapat ditentukan dengan menganalisis reaksi bahan dalam selang waktu tertentu, sehingga konsetrasi reaktan dan produk reaksi dapat diketahui. Konsentrasi awal zat dan orde reaksi mempengaruhi persamaan laju reaksi. Orde reaksi mempengaruhi laju rekasi jika

$$
v=-\frac{d[A]}{d t}
$$

Karena laju reaksi berbanding lurus dengan konsentrasi zat pereksi sehingga dapat menggunakan laju terintegrasi pada persamaan (12) berikut

$$
\begin{aligned}
& -\frac{d[A]}{d t}=k[A]_{t}^{n} \\
& -\int \frac{d[A]}{[A]_{t}^{2}}=\int k d t
\end{aligned}
$$

Dengan $n=$ orde reaksi, $k=$ konstanta laju reaksi, $t=$ waktu. Untuk orde reaksi orde dua yang telah diintegralkan diperoleh

$$
\frac{1}{[A]_{t}}=k t+c
$$

Perubahan porositas terhadap waktu didapatkan dengan menggunakan hukum/kekekalan massa yaitu perubahan rata-rata massa dalam kontrol volume ditambah dengan arus massa yang melalui kontrol volume sama dengan banyak massa yang diciptakan dari sumbernya atau hilang. Menurut teorema pengangkutan Reynold

Rate of change of mass in cell + net outward mass flux $=0$

$$
\frac{d}{d t}(\rho \forall)+\sum_{\text {faces }} \rho \mathrm{u} \cdot A=0
$$

Jika volume kendali diperbesar dan digambarkan arah aliran massanya dari permukaan yang berjarak $\Delta x$ dari pusat elemen dinyatakan berturut-turut sebagai $\rho u \phi$ dan $\rho u \phi+\frac{\partial(\rho u \phi)}{\partial x} \Delta x$ dapat ditunjukkan pada gambar 2 berikut

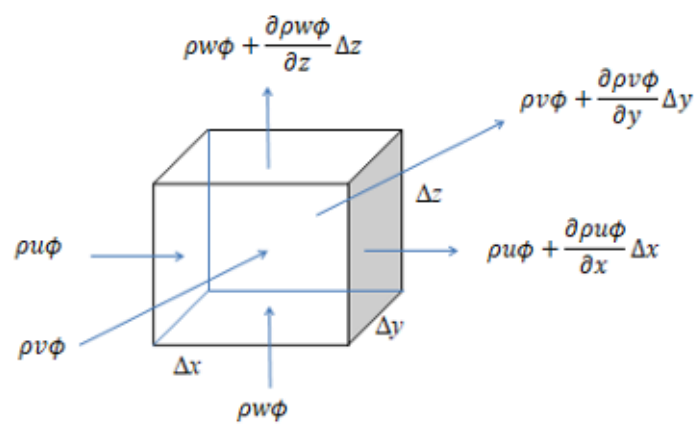

Gambar 2. Volume Kendali Aliran Massa
Dengan menggunakan aliran massa pada gambar 2, maka persamaan (15) dapat dijabarkan menjadi

$$
\begin{aligned}
& \frac{\partial}{\partial t}(\rho \phi \forall)\left(\rho u \phi+\frac{\partial \rho u \phi}{\partial x} \Delta x-\rho u \phi\right) \Delta y \Delta z+\frac{\partial}{\partial t}(\rho \phi \forall)\left(\rho v \phi+\frac{\partial \rho v \phi}{\partial y} \Delta y-\rho v \phi\right) \\
& \Delta x \Delta z+\frac{\partial}{\partial t}(\rho \phi \forall)\left(\rho w \phi+\frac{\partial \rho w \phi}{\partial z} \Delta z-\rho w \phi\right) \Delta x \Delta y=0
\end{aligned}
$$

Persamaan (36) dibagi dengan $\Delta x \Delta y \Delta z$ dan diasumsikan aliran incompressible maka $\rho$ konstan dan ditambahkan dengan komponen transfer massa dari hasil reaksi kimia sehingga diperoleh

$$
\rho\left(\frac{\partial \phi}{\partial t}+\frac{\partial u \phi}{\partial x}+\frac{\partial v \phi}{\partial y}+\frac{\partial w \phi}{\partial z}\right)+\Gamma=0
$$

Dengan $\Gamma=k A\left(c-c_{e q}\right)$ dan $\phi$ merupakan porositas gambut, $k$ merupakan laju reaksi, $A$ merupakan luas permukaan, $c$ merupakan konsentrasi actual dan $c_{e q}$ konsentrasi seimbang.

Dengan menggunakan turunan parsial maka didapatkan

$\frac{\partial \phi}{\partial t}+u \frac{\partial \phi}{\partial x}+v \frac{\partial \phi}{\partial y}+w \frac{\partial \phi}{\partial z}+\phi \frac{\partial u}{\partial x}+\phi \frac{\partial v}{\partial y}+\phi \frac{\partial w}{\partial z}=\frac{k A\left(c-c_{e q}\right)}{\rho}$

Karena aliran berupa incompressible maka $\frac{\partial u}{\partial x}+\frac{\partial v}{\partial y}+\frac{\partial w}{\partial z}=0$ dan dalam arah longitudinal diperoleh

$$
\frac{\partial \phi}{\partial t}=-\left(u \frac{\partial \phi}{\partial x}\right)-\frac{k A\left(c-c_{e q}\right)}{\rho}
$$

Dengan mensubtitusikan persamaan (5) kedalam persamaan (19) diperoleh model untuk angka pori diperoleh

$$
\frac{\partial e}{\partial t}=-\left(u \frac{\partial e}{\partial x}\right)-(1+e)^{2} \frac{k A\left(c-c_{e q}\right)}{\rho}
$$

Untuk memudahkan simulasi. persamaan (20) dibentuk kedalam persamaan non dimensional dengan variable tanpa dimensi yang diperkenalkan sebagai berikut.

$e=e_{0} e^{*} \quad x=L_{0} x^{*} \quad t=\frac{L_{0}}{U_{0}} t^{*} \quad \rho=\rho_{0} \rho^{*} \quad k=U_{0} k^{*}$

Persamaan non dimensional untuk model angka pori diperoleh

$$
\frac{\partial e}{\partial t}=-\left(u \frac{\partial e}{\partial x}\right)-(1+e)^{2} \frac{L_{0} k A\left(c-c_{e q}\right)}{e_{0} \rho_{0} \rho}
$$

Selanjutnya persamaan (21) diselesaikan secara numerik menggunakan metode beda hingga skema MacCormack. Tahap prediktor

$e_{i, j, k}^{\overline{n+1}}=e_{i, j, k}^{n}+\Delta t\left(-\left(u_{i, j, k}^{n} \frac{e_{i+1, j, k}^{n}-e_{i, j, k}^{n}}{\Delta x}\right)-(1+e)^{2} \frac{L_{0} k A c_{0}\left(c-c_{e q}\right)}{e_{0} \rho_{0} \rho}\right)$

Tahap korektor

$e_{i, j, k}^{n+1}=\frac{1}{2}\left[e_{i, j, k}^{n}\left[e_{i, j, k}^{n+1}+\Delta t\left(-\left(u_{i, j, k}^{n} \frac{e_{i, j, k}^{n}-e_{i-1, j, k}^{n}}{\Delta x}\right)-(1+e)^{2} \frac{L_{0} k A c_{0}\left(c-c_{e q}\right)}{e_{0} \rho_{0} \rho}\right)\right]\right]$ 
Hasil simulasi numerik menggunakan metode beda hingga skema MacCormack untuk laju reaksi kimia, porositas dan angka pori gambut yang ditunjukkan pada masing-masing gambar berikut.

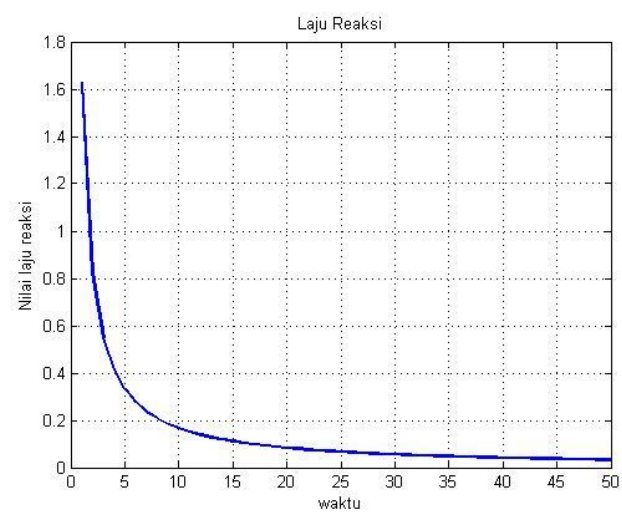

Gambar 3. Laju Reaksi

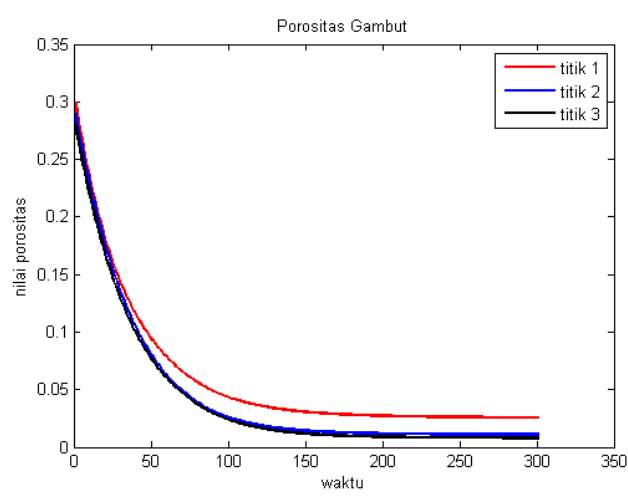

Gambar 4. Porositas Gambut

\section{PENUTUP}

\section{Simpulan}

Berdasarkan simulasi dari model yang dihasilkan cukup dapat merepresentasikan kondisi nyata, terutama jika dibandingkan dengan hasil laboratorium yang telah dilakukan oleh peneliti lain sebelumnya. Dengan penambahan parameter yang lebih tepat akan memberikan model yang lebih signifikan.

\section{Saran}

Saran untuk penelitian lebih lanjut dapat menggunakan sifat fisik gambut yang lain misalnya kadar air dan diselesaikan dengan menggunakan metode lain untuk menyelesaikan permasalahan yang lebih kompleks lagi.

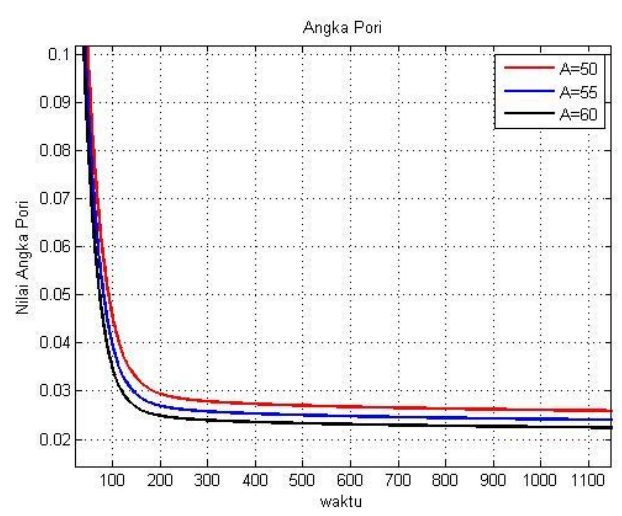

Gambar 5. Angka Pori

Pada plot gambar 3 diketahui bahwa konsentrasi laju reaksi pada reaktan mengalami penurunan setiap waktu. Penurunan tersebut berlangsung hingga mendekati nol yang artinya pada saat waktu tertentu proses reaksi kimia akan berhenti.

Pada Plot gambar 4 diketahui terdapat kecenderungan nilai porositas dari tanah mengalami penurunan seiring bertambahnya waktu hingga penurunan tersebut sampai pada kondisi konstan, dimana kondisi ini reaksi kimia yang terjadi sudah melemah.

Kondisi yang sama ditunjukkan oleh plot gambar 5 diketahui nilai angka pori memiliki kecenderungan turun. Berdasarkan perbandingan luas penampang yang ada, diketahui bahwa semakin luas penampang maka nilai angka pori menjadi semakin kecil.

\section{UCAPAN TERIMA KASIH}

Artikel ilmiah ini merupakan luaran dari penelitian dosen pemula tahun 2018 didanai oleh Direktorat Riset dan Pengabdian Kepada Masyarakat, Direktorat Jenderal Penguatan Riset dan Pengembangan, Kementrian Riset, Teknologi dan Pendidikan Tinggi pada kontrak pendanaan bulan April 2018

\section{DAFTAR PUSTAKA}

Ma'ruf, M. A., \& Syauqiah, I. (2017). Efek Waktu Pemeraman Terhadap Karakteristik Sifat Fisik Tanah Gambut dengan Bahan Stabilisasi Serbuk Kayu. Infoteknik, 333-344.

Ma'ruf, M. A., \& Yulianto, F. E. (2017). Tanah Gambut Berserat: Solusi Dan Permasalahannya Dalam Pembangunan Infrastruktur Yang Berwawasan Lingkungan. INFO-TEKNIK, 279-292.

Pradana, M. S., \& Muniroh, L. (2016). METODE ADI (ALTERNATING DIRECT IMPLICIT) PADA PENYELESAIAN MODEL ALIRAN AIR 
TANAH. Unisda Journal of Mathematics and Computer Science (UJMC), 2(1), 69-78.

Pradana, M. S., \& Rohmah, A. M. (2018). PEMODELAN KADAR AIR PADA SIFAT FISIK STABILISASI TANAH GAMBUT. Journal of Mathematics and Mathematics Education, 8(1).

Pradana, M. S., \& Widodo, B. (2014). Model Pertumbuhan Kristal Pada Gambut (XVII). Surabaya: Konfrensi Nasional Matematika XVII. Retrieved from http://knm17.its.ac.id/

Yulianto, F. E., \& Mochtar, N. E. (2012). Behavior of Fibrous Peat Soil Stabilized with Rice Husk Ash
(RHA) and Lime. In Proceedings of 8th International Symposium on Lowland Technology September (pp. 11-13).

Yulianto, F. E., Mochtar, N. E., \& Wardani, M. K. (2016). The Effect Of Water Pore Condition To Shear Strength And Compression Behavior Of Stabilized Fibrous Peat Mixing Lime Caco3 And Rice Husk Ash. International Journal of Applied Engineering Research, 11(15), 8578-8582.

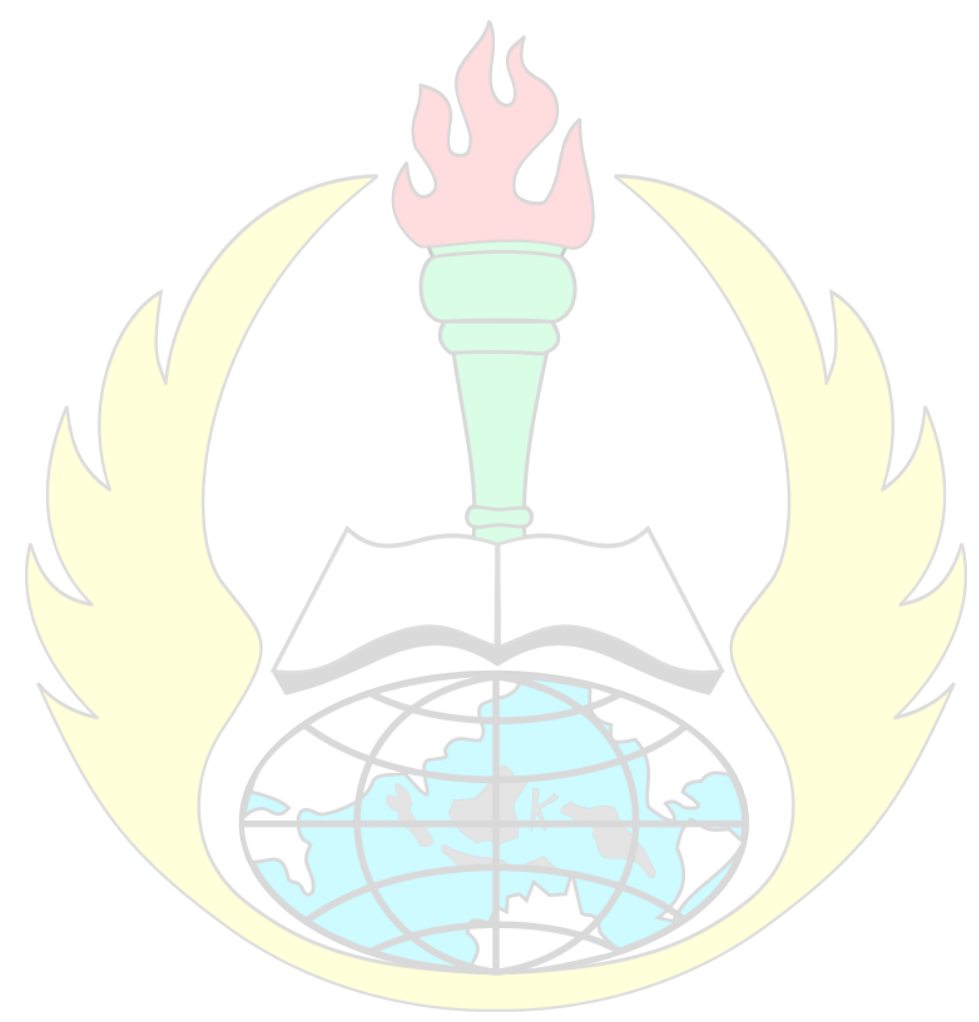




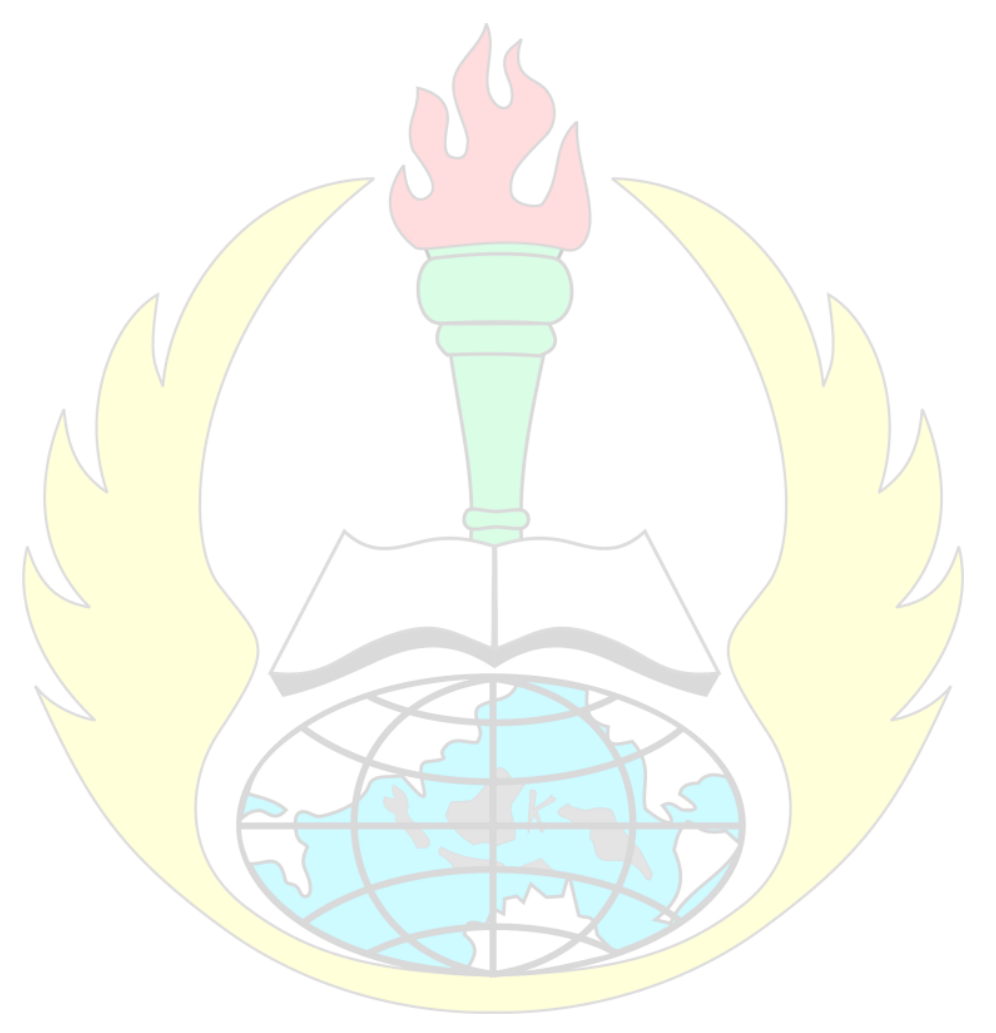

